\title{
Evaluation of agronomic, physiological, agro-physiological, recovery and utilization effeciencies in three cultivars of soybean
}

\section{Sadegh Beaicknejad}

Msc Agronomy, Genetics and Agricultural Biotechnology Institute of Tabarestan, Sari Agricultural Sciences and Natural Resources University, Sari, Iran

\section{ABSTRACT}

Effect of different levels of potassium fertilizer on agronomic efficiency (AE), physiological efficiency (PE), agrophysiological efficiency (APE), apparent recovery efficiency (ARE) and utilization efficiency (UE) in three cultivars of soybean was investigated using an experiment with a factorial arrangement based on completely randomized block design with three blocks in the Daronkola located at Babol, Iran during 2012-2013 growing season. The treatments consisted of potassium phosphate fertilizer that was utilized at three levels $(0,100,200 \mathrm{kgr} / \mathrm{hectare})$ and three cultivars of Soybean included 032 (G1), 033 (G2) and JK (G3). The results showed that Potassium were significant effect on PE, APE, ARE and UE in one percent level $(\mathrm{P}<0.01)$. In all of cultivars, potassium enhancement increased UE and APE, but caused decrease ARE. Difference between potassium treatments in all of cultivars in ARE index was Significant.

\section{KEY WORDS: POTASSIUM, SOYBEAN, CULTIVAR}

\section{INTRODUCTION}

The origin and history forms the soybean is not known, it is might said that the soybean is native to East Asia (Adcock et al, 2003). The soybean crop is one of the most important crops world. Soybean grains are important as protein meal and vegetable oil. Soybean contains whole protein that supplies all essential amino acids required for human health, carbohydrate, fatty acids, and minerals (Friedman and Brandon, 2001). Soybean oil is rich in polyunsaturated fatty acids, including the two essential fatty acids, linoleic and linolenic, that are not produced in the body. Linoleic and linolenic acids help the uptake of vital nutrients needed for human health (Friedman

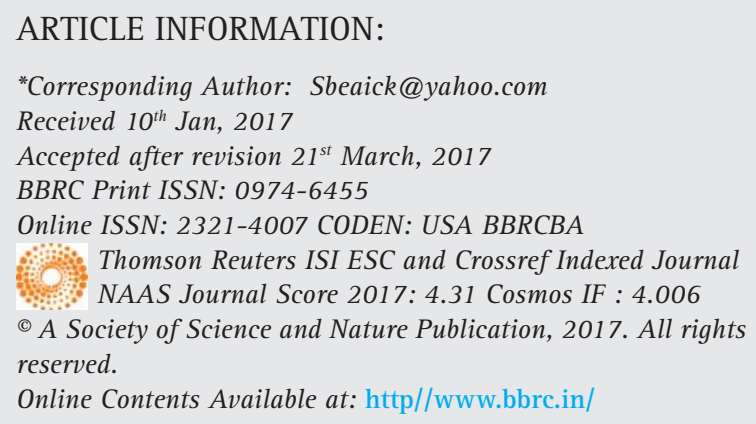


and Brandon, 2001).Potassium is an essential nutrient involved in regulating water balance, increasing water uptake, enhancement of pest and disease resistance and also involved in almost all processes needed to sustain plant life (Tiwari et al, 2001 Mehdi et al, 2007, Hartman et al., 2011 and Hosseini et al (2016).

Soybean takes up and removes large amounts of potassium from soil than any other nutrient (Tiwari et al, 2001). Potassium utilization increased the number of pods and also used a beneficial influence on retaining pods until harvest in soybean (Coale and Grove, 1990). Young seedlings of soybean do not utilize much potassium, but the uptake rate goes up to a peak during the period of rapid vegetative growth. The potassium in vegetative parts is moved to seed during pod fill process. The mature soybean seed is having almost $60 \%$ of the total potassium in plant (Hoeft et al., 2000).

Potassium quantity changes in different soils and annually fertilizers utilization is necessary in some soils because of potassium lack. In some soils, potassium amount is too high so that even after years of plant cultivation and leaching which discharges potassium from soil, there is no require using fertilizers (Shahdi Komleh, 2002). Tiwari, et al (2001) reported that adding potassium fertilizer to soil caused increase soybean yield. Stino et al. (2002) reported application of potassium improve crop yield. Hosseini et al. (2016) expressed that increasing potassium uptake caused improves crop yield and component yield.

Potassium fertilizer has inattentively utilized in Iran in regard to intensive cultivation. Because of more potassium extracts from soil by the crops, the soil available potassium rate tends to reduce, quickly. So, excessive application of potassium on the agricultural lands is an indicator of the importance of paying attention to these nutrients (Malakouti, 2004). The objective of this research was to investigate effect potassium fertilizer on agronomic efficiency (AE), physiological efficiency (PE), agro-physiological efficiency (APE), apparent recovery efficiency (ARE) and utilization efficiency (UE) in three cultivars of soybean.

\section{MATERIALS AND METHODS}

\section{STUDY AREA AND EXPERIMENTAL SETUP}

This research was carried out in research farm located at the Daronkola located at Babol, Iran during 20122013 growing season which used factorial arrangement based on completely randomized block design with three blocks. Each experimental plot had 5 meters long and 3 meters $(3 \mathrm{~m} \times 5 \mathrm{~m})$ wide and 6 ridges spaced $50 \mathrm{~cm}$ apart. Uniform healthy soybean seeds were purchased from Iran's Oilseed Research and Development Company Deputy of Sari, Iran. Seeds were used for hand sowing in the month of June, 2012 after removing the trashes and impurities.

\section{TREATMENT}

The treatments consisted of potassium phosphate fertilizer that was utilized at three levels $(0,100,200 \mathrm{kgr} / \mathrm{hec}-$ tare) and three cultivars of Soybean included 032 (G1), 033 (G2) and JK (G3).

\section{STATISTICAL ANALYSIS}

Data analysis included the analysis of variance, mean comparisons and correlations which was done using SPSS software. agronomic efficiency (AE), physiological efficiency (PE), agro-physiological efficiency (APE), apparent recovery efficiency (ARE) and utilization efficiency (UE) were calculated by using the following equations (Baligar et al., 2001):

$$
\mathrm{AE}\left(\mathrm{mg} \mathrm{mg}^{-1}\right)=\frac{\mathrm{GY}_{\mathrm{f}} \text { in } \mathrm{mg}-\mathrm{GY}_{\mathrm{uf}} \text { in } \mathrm{mg}}{\mathrm{K} \text { applied in } \mathrm{mg}}
$$

Where, $\mathrm{GY}_{\mathrm{f}}=$ Grain yield of fertilized pot, $\mathrm{GY}_{\mathrm{uf}}=$ Grain yield of unfertilized pot.

$$
\mathrm{PE}\left(\mathrm{mg} \mathrm{mg}^{-1}\right)=\frac{\mathrm{BY}_{\mathrm{f}} \text { in } \mathrm{mg}-\mathrm{BY}_{\mathrm{uf}} \text { in } \mathrm{mg}}{\mathrm{UK}_{\mathrm{f}} \text { in grain and strew in } \mathrm{mg}-\mathrm{UK}_{\mathrm{uf}} \text { in grain and strew in } \mathrm{mg}}
$$

Where, $\mathrm{BY}_{\mathrm{f}}=$ Biological yield (grain + straw) of fertilized pot, $\mathrm{BY}_{\mathrm{uf}}=$ Biological yield of unfertilized pot, $\mathrm{UK}_{\mathrm{f}}=$ Uptake of $\mathrm{K}$ in grain plus straw of fertilized pot and $\mathrm{UK}_{\mathrm{uf}}=$ Uptake of potassium in grain and straw of unfertilized pot

$$
\operatorname{APE}\left(\mathrm{mg} \mathrm{mg}^{-1}\right)=\frac{\mathrm{GY}_{\mathrm{f}} \text { in } \mathrm{mg}-\mathrm{GY}_{\mathrm{uf}} \text { in } \mathrm{mg}}{\mathrm{UK}_{\mathrm{f}} \text { in grain and strew in } \mathrm{mg}-\mathrm{UK} \mathrm{Ku}_{\mathrm{uf}} \text { in graln and strew in } \mathrm{mg}}
$$

Where, $\mathrm{GY}_{\mathrm{f}}=$ Grain yield of fertilized pot, $\mathrm{GY}_{\mathrm{uf}}=$ Grain yield of unfertilized pot, $\mathrm{UK}_{\mathrm{f}}=$ Uptake of potassium in grain plus straw of fertilized pot and $\mathrm{UK}_{\mathrm{uf}}=$ Uptake of potassium in grain and straw of unfertilized pot.

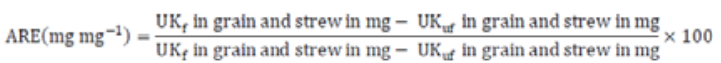

Where, $\mathrm{UK}_{\mathrm{f}}=$ Uptake of $\mathrm{K}$ in fertilized pot, $\mathrm{UK}_{\mathrm{uf}}=$ Uptake of $\mathrm{K}$ in unfertilized pot, $\mathrm{UK}_{\mathrm{f}}=$ Uptake of potassium of fertilized pot and UKuf = Uptake of potassium in unfertilized pot.

$$
\mathrm{UE}\left(\mathrm{mg} \mathrm{mg}^{-1}\right)=\mathrm{PE} \times \mathrm{ARE}
$$

\section{RESULTS AND DISCUSSION}

Differences between treatments for the AE, PE, APE, ARE and $U E$ were significant $(P<0.01)$ but was significant 


\begin{tabular}{|l|l|l|l|l|l|l|}
\hline \multicolumn{6}{|l|}{ Table 1. Mean squares of various indices of soybean plants. } \\
\hline S.O.V & Df & AE & PE & APE & ARE & UE \\
\hline Replication & 2 & 0.169 & 779550.431 & 19015.438 & 6.167 & 2573.070 \\
\hline treatment & 5 & $3.520^{*}$ & $5444303.031^{* *}$ & $1346676.925^{* * *}$ & $54.767^{* * *}$ & $23112.646^{* * *}$ \\
\hline Error & 10 & 0.781 & 163350.096 & 64936.201 & 3.633 & 2857.809 \\
\hline
\end{tabular}

effected on $\mathrm{AE}$ in five percent level $(\mathrm{P}<0.05)$ (table 1$)$. Farrokh and Farrokh (2012) reported that effect of potassium and cultivator on agronomy efficiency of potassium, physiological efficiency of potassium and recovery efficiency of potassium was significant $(\mathrm{P}<0.01)$.

Potassium use efficiency stated in different ways (agronomic, physiological, agro-physiological, recovery and utilization) is presented in figures 1, 2, 3, 4 and 5. Agronomic efficiency (AE) varied from 2.3 to $4.5 \mathrm{mg}$ $\mathrm{mg}^{-1}$. The highest and lowest value of AE was related to G2 and G3 cultivar in $100 \mathrm{kgr}$ per hectare of potassium, respectively. There were significant differences between treatments. In G1 and G3 cultivars, Addition of potassium caused increase AE (figure 1).

Physiological efficiency(PE) values changed from 1300 to $4700 \mathrm{mg} \mathrm{mg}^{-1}$. The PE value was greater in G1 cultivar with $200 \mathrm{kgr}$ per hectare of potassium than other treatments. Lowest value of PE was seen in G2 cultivar with $100 \mathrm{kgr}$ per hectare of potassium. There were significant differences between potassium treatments in G1 cultivar. In G1 and G2 cultivars, Addition of potassium caused increase PE but reduced PE in G3 cultivar (figure 2).

Agro-physiological efficiency (APE) values varied from 1700 to $3700 \mathrm{mg} \mathrm{mg}^{-1}$. The APE was less in G3 cultivar with $100 \mathrm{kgr}$ per hectare of potassium than other treatments. The highest value of APE was related to G1 in $200 \mathrm{kgr}$ per hectare of potassium. There were significant differences between potassium treatments in G1 and G3 cultivars. In all of cultivar, enhancement of potassium caused increase APE (figure 3).

Figure 4 showed that apparent recovery efficiency (ARE) varied from 7.87 to $18 \%$. ARE index was more in G3 cultivar with $100 \mathrm{kgr}$ per hectare of potassium than other treatments. In all of cultivar, enhancement of potassium caused reduce ARE. There were significant differences between potassium treatments in all of cultivars.

The utilization efficiency (UE) varied from 310 to 550 $\mathrm{mg} \mathrm{mg}^{-1}$. The highest and lowest value of UE was related to G3 cultivar with 200 and $100 \mathrm{kgr}$ per hectare of potassium, respectively. There were not significant differences between potassium treatments in G2 cultivars but were seen significant differences between potassium treatments in G1 and G2 cultivars. In all of cultivar, addition of potassium caused increase UE (figure 5). Genotypic differences in efficiency of potassium uptake and application in all major economically important plants and also differential exudation of organic compounds to facilitate release of non-exchangeable potassium is one of the mechanisms of different potassium uptake efficiency (Rengel and Damon, 2008). Fageria et al (2014) expressed that potassium use efficiency defined in the several ways (agronomic efficiency, physiological effi-

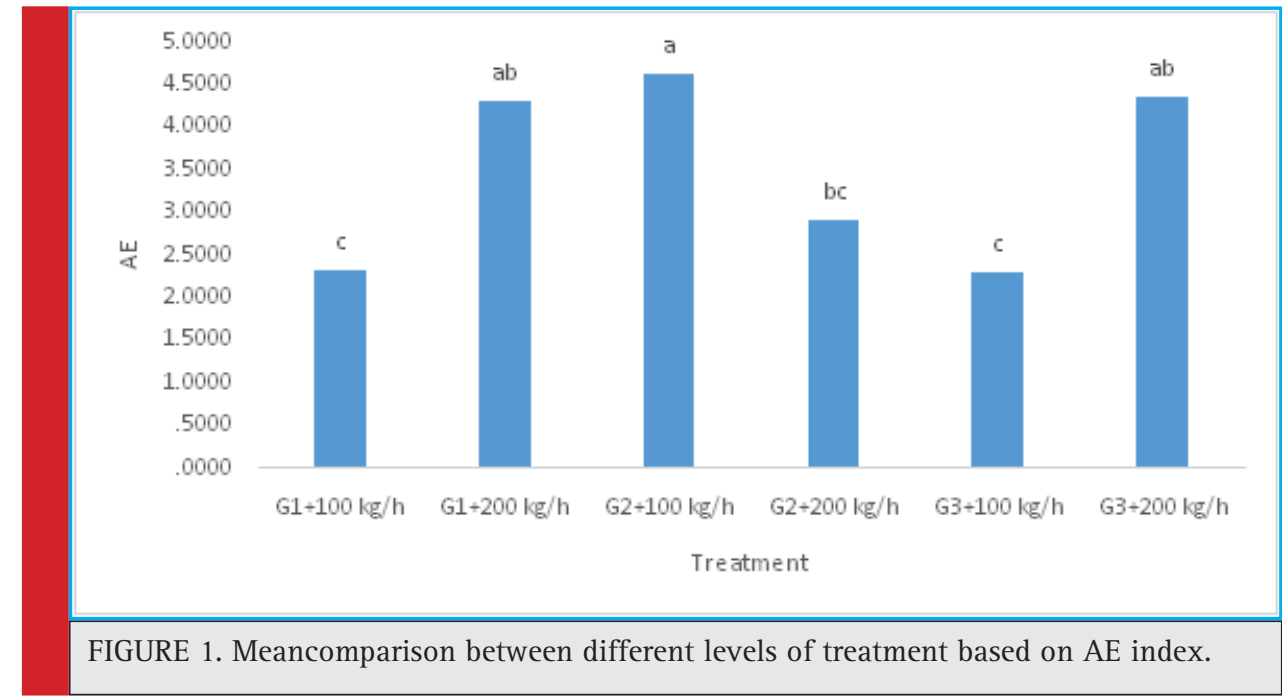



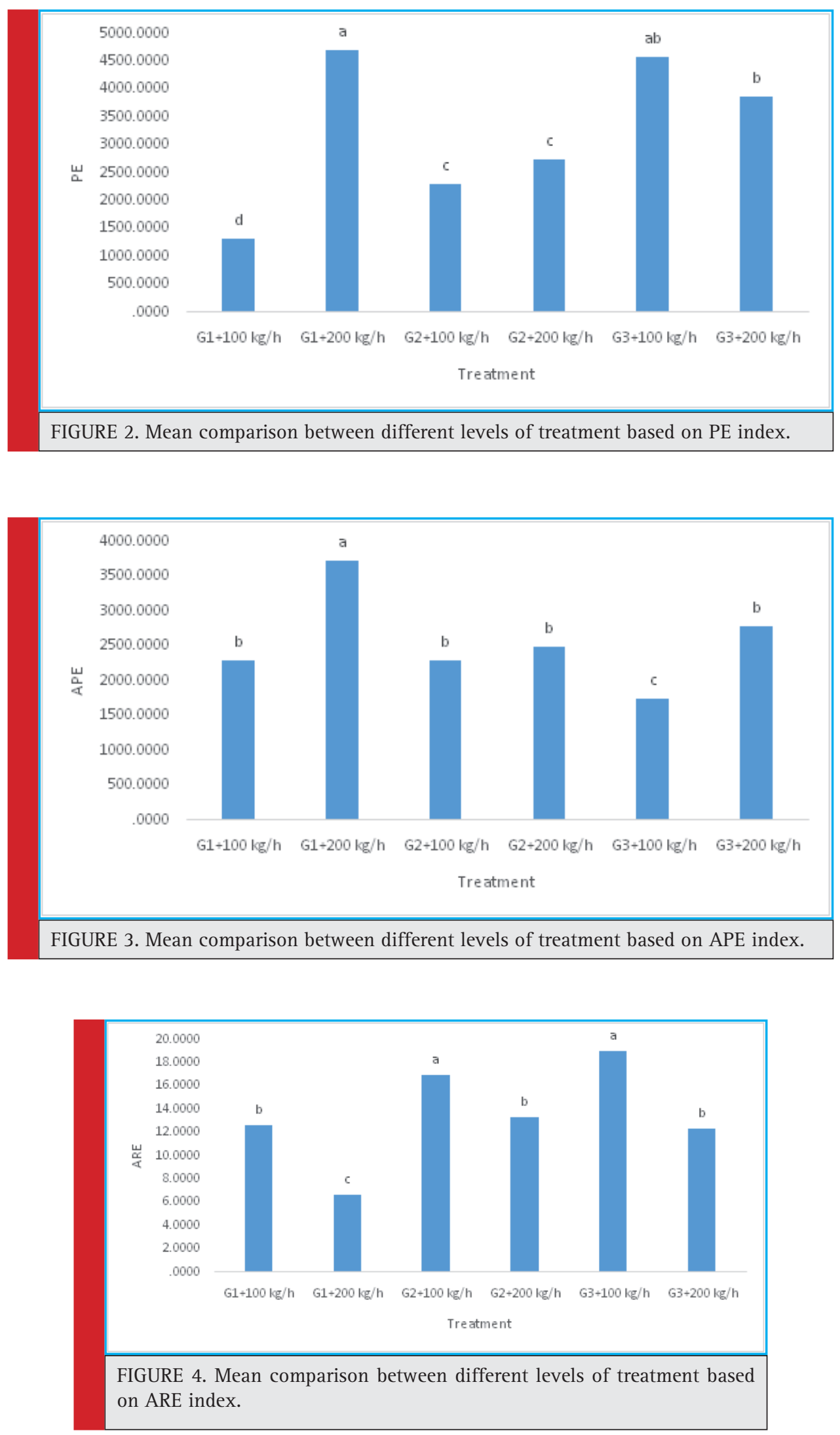


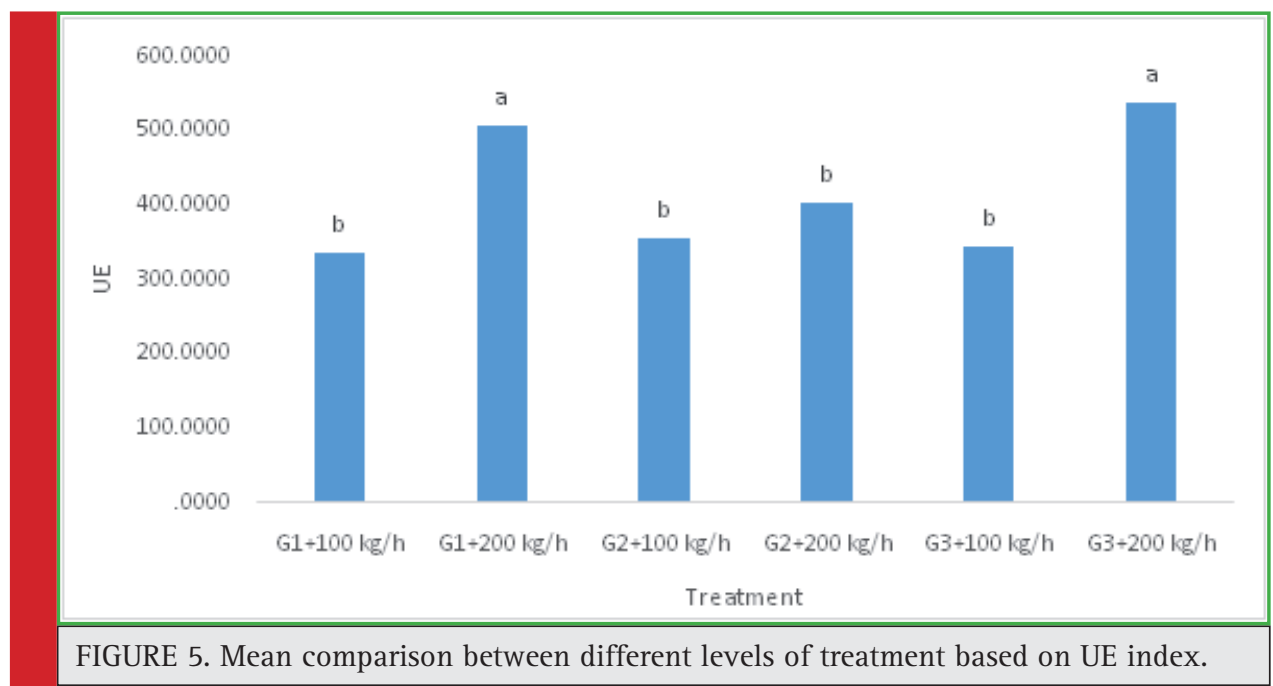

ciency, agro-physiological efficiency, apparent recovery efficiency and utilization efficiency) varied among cultivars.

Table 2 showed that was positive, high and significant correlation between UE and APE but was negative between ARE and APE. Also, there was negative high and significant correlation between UE and ARE.

Table 3 showed that there was high and significant correlation between indexes in G1 cultivar of plant. Highest correlation was between UE and AE that its

\begin{tabular}{|c|c|c|c|c|c|}
\hline Indices & $\mathrm{AE}$ & PE & APE & ARE & UE \\
\hline $\mathrm{AE}$ & 1 & & & & \\
\hline PE & 0.219 & 1 & & & \\
\hline APE & $0.496^{*}$ & 0.321 & 1 & & \\
\hline ARE & -0.345 & -0.147 & $-0.781^{* * *}$ & 1 & \\
\hline UE & $0.573^{*}$ & $0.565^{*}$ & $0.670^{* * *}$ & $-0.605^{* * *}$ & 1 \\
\hline
\end{tabular}

Table 3. A matrix of simple correlation coefficient for the estimated indices of G1 plants.

\begin{tabular}{|l|l|l|l|l|l|}
\hline Indices & $\mathrm{AE}$ & $\mathrm{PE}$ & $\mathrm{APE}$ & $\mathrm{ARE}$ & $\mathrm{UE}$ \\
\hline $\mathrm{AE}$ & 1 & & & & \\
\hline $\mathrm{PE}$ & $0.910^{*}$ & 1 & & & \\
\hline $\mathrm{APE}$ & $0.932^{* * *}$ & $0.951^{* *}$ & 1 & & \\
\hline ARE & $-0.942^{* *}$ & $-0.823^{*}$ & $-0.850^{*}$ & 1 & \\
\hline UE & $0.952^{* * *}$ & $0.919^{* * *}$ & $0.876^{*}$ & $-0.844^{*}$ & 1 \\
\hline **Significant at the $1 \%$ level; *Significant at the 5\% level. \\
\hline
\end{tabular}

Table 4. A matrix of simple correlation coefficient for the estimated indices of G2 plants.

\begin{tabular}{|l|l|l|l|l|l|}
\hline Indices & AE & PE & APE & ARE & UE \\
\hline AE & 1 & & & & \\
\hline PE & -0.641 & 1 & & & \\
\hline APE & -0.235 & $0.834^{*}$ & 1 & & \\
\hline ARE & 0.632 & -0.326 & 0.135 & 1 & \\
\hline UE & -0.487 & 0.692 & 0.731 & -0.043 & 1 \\
\hline **Significant at the 1\% level; *Significant at the 5\% level. \\
\hline 7
\end{tabular}

value was 0.952. Correlation between APE and PE was 0.951.

There was positive, high and significant correlation between PE and APE. But the rest of correlations were not significant (Table 4).

There was positive, high and significant correlation between UE and AE. Also between UE and ARE in G3 cultivar of plant (Table 5).

\begin{tabular}{|c|c|c|c|c|c|}
\hline Indices & $\mathrm{AE}$ & $\mathrm{PE}$ & APE & ARE & UE \\
\hline $\mathrm{AE}$ & 1 & & & & \\
\hline PE & -0.352 & 1 & & & \\
\hline APE & 0.670 & -0.714 & 1 & & \\
\hline ARE & $-0.899 *$ & 0.454 & -0.781 & 1 & \\
\hline UE & $0.823^{*}$ & -0.335 & 0.754 & $-0.960^{* * *}$ & 1 \\
\hline
\end{tabular}




\section{CONCLUSIONS}

Potassium treatments were significant effect on PE, APE, ARE and UE $(\mathrm{P}<0.01)$. In all of cultivars, Addition of potassium caused increase UE and APE, but caused reduce ARE. Among indexes, there were significant differences between potassium treatments in all of cultivars in ARE index. The high, positive and significant correlations were seen between UE and AE, APE and PE in plants of G1 cultivar.

\section{REFERENCES}

Adcock, D., McNeill, A., Unkovich, M., \&t O'Leary, G. (2003). Water use efficiency of wheat in a semi-arid environment. In Solutions for a better environment: Proceedings of the 11th Australian Agronomy Conference, Geelong, Victoria, Australia, 2-6 February 2003. (pp. 0-4). Australian Society of Agronomy Inc., Victorian Institute for Dryland Agriculture.

Baligar, V. C., Fageria, N. K., \&t He, Z. L. (2001). Nutrient use efficiency in plants. Communications in Soil Science and Plant Analysis, 32(7-8), 921-950.

Coale, F. J., \&t Grove, J. H. (1990). Root distribution and shoot development in no-till full-season and double-crop soybean. Agronomy Journal, 82(3), 606-612.

Farrokh, A. R., \& Farrokh, A. (2012). Effect of nitrogen and potassium on yield, agronomy efficiency, physiological efficiency and recovery efficiency of nitrogen and potassium in flue cured tobacco. Intl J Agri Crop Sci, 4(12), 770-778.

Friedman, M., \&t Brandon, D. L. (2001). Nutritional and health benefits of soy proteins. Journal of Agricultural and Food Chemistry, 49(3), 1069-1086.

Hartman, G. L., West, E. D., \& Herman, T. K. (2011). Crops that feed the World 2. Soybean-worldwide production, use, and constraints caused by pathogens and pests. Food Security, 3(1), 5-17.
Hoeft, R. G., Aldrich, S. R., Nafziger, E. D., \&t Johnson, R. R. (2000). Modern corn and soybean production.

Hosseini, M., Naeini, S. A. M., Dehghani, A. A., \&t Khaledian, Y. (2016). Estimation of soil mechanical resistance parameter by using particle swarm optimization, genetic algorithm and multiple regression methods. Soil and Tillage Research, 157, 32-42.

Malakouti MJ (2004) Fertilizer use by crops in Iran. A report prepared for FA0, Soil and Water Research Institute, Tehran, Iran.

Mehdi, S. M., Sarfraz, M., \&t Hafeez, M. (2007). Response of rice advance line PB-95 to potassium application in salinesodic soil. Pakistan journal of biological sciences: PJBS, 10(17), 2935-2939.

N. K. Fageria 1, H. R. Gheyi2 and M. C. S. Carvalho. (2014). Yield, potassium uptake and use efficiency in upland ricecultivars. Inovargi international meeting. 4514-4520.

Rengel, Z., \&t Damon, P. M. (2008). Crops and cultivars differ in efficiency of potassium uptake and use. Physiologia Plantarum, 133(4), 624-636.

Shahdi Komleh, A. (2002). The effect potassium on removing of growth disorter related to shortnes of Guilan rice field (pp. 13-17). Rice Research Institute.

Stino GR, Aziz AE, Elezaby AA, and Abd Elmoneim EA (2002) Response of Valencia orange tree to the foliar application of different potassium salts: Their effects on the veget tive growth, leaf miner infestation and leaf mineral contents. Hort Science, 35(3). 421-427.

Tiwari, S. P., Joshi, 0. P., Vyas, A. K., \& Billore, S. D. (2002). Potassium nutrition in yield and quality improvement of soybean. In Proceedings of the International Symposium on Potassium for Sustainable Crop Production (pp. 307-321).

Tiwari, S.P., Joshi O.P., Vyas, A.K. and Billore, S.D. (2001) Potassium Nutrition in Yield and Quality. 307-320. 